\title{
ANALISIS KESALAHAN SISWA DALAM MENYELESAIKAN SOAL EKSPONEN MELALUI PEMBELAJARAN ONLINE DI MASA PANDEMI KELAS X SMA SWASTA TAMANSISWA BINJAI
}

\author{
${ }^{1}$ Desvita Angraini, ${ }^{2}$ R. Maisaroh R. Siregar \\ ${ }^{I}$ Mahasiswa STKIP Budidaya Binjai, ${ }^{2}$ Dosen STKIP Budidaya Binjai \\ Iemail : desvitangraini@gmail.com,2email: maisarohsrg@gmail.com
}

\begin{abstract}
ABSTRAK
Penelitian ini bertujuan untuk mendeskripsikan kesalahan yang paling banyak dilakukan siswa dalam menyelesaikan soal eksponen, serta mendeskripsikan kesalahan-kesalahan yang dilakukan siswa dalam menyelesaikan soal eksponen. Jenis penelitian ini adalah deskriptif kuantitatif, dengan populasi penelitian yaitu seluruh siswa kelas X SMA Swasta Tamansiswa Binjai. Dengan teknik Random Sampling, diperoleh sampel penelitian dari kelas X IPA 1 yang berjumlah 33 siswa. Teknik pengumpulan data yang digunakan adalah tes diagnostik dan dokumentasi. Berdasarkan hasil penelitian kesalahan yang dilakukan siswa sebagai berikut : (1) Kesalahan yang paling banyak dilakukan siswa dalam menyelesaikan soal eksponen melalui pembelajaran online dimasa pandemi kelas X SMA Swasta Tamansiswa Binjai adalah kesalahan proses penyelesaian. (2) Pada pertemuan I, Kesalahan Konsep (19,71\%), Kesalahan Prinsip (37,87\%), Kesalahan Proses Penyelesaian (77,27\%). Sedangkan pertemuan II yaitu, Kesalahan Konsep $(10,61 \%)$, Kesalahan Prinsip (46,97\%), Kesalahan Proses Penyelesaian (65,15\%). Kemudian, solusi untuk mengurangi kesalahan siswa dalam menyelesaikan soal eksponen diantaranya yaitu menyusun program perbaikan, model pembelajaran yang diberikan harus lebih kreatif, siswa harus lebih teliti dalam mengerjakan soal-soal, guru harus lebih dekat dengan siswa untuk mengetahui masalah yang dialami siswa yang dapat menyebabkan terjadinya kesalahan dalam menyelesaikan soal, dan lain sebagainya.
\end{abstract}

Kata Kunci : analisis kesalahan, eksponen, masa pandemi

\begin{abstract}
This study aims to describe the most mistakes made by students in resolving the exponential questions, and describe the mistakes made by students in resolving the exponential problems. This kind of research is a quantitative description, with the research population namely all students in X grade of SMA Swasta Tamansiswa Binjai. With the random sampling technique, the research sample was obtained from class X IPA 1, totaling 33 students. The techniques of collection data used were diagnostic tests, interviews, and documentation. Based on the results of the research, the errors made by students were as follows: (1) The most mistake students made in resolving exponen problems through online learning during the pandemic of class $X$ at SMA SWATA Tamansiswa Binjai are a mistake in the completion process. (2) At the first meeting, Concept Error (19.71\%). Principle Error (37.87\%), Completion Process Error (77.27\%). While the second meeting, namely, Concept Error (10.61\%), Principle Error (46.97\%), Completion Process Error (65.15\%). Then, solutions to reduce student errors in solving exponential questions include preparing a repair program, the given learning model should be more creative, students should be more thorough in their problems, teachers must be closer to the students to know the problems experienced by students that can cause errors in solving problems, and so on.
\end{abstract}

Key Words : analysis of errors, exponential, pandemic time 


\section{PENDAHULUAN}

Mewabahnya sebuah virus pada tahun 2019 yang dikenal dengan Covid-19 (Corona Virus Disease 19) secara terus menerus menyebabkan pandemi Covid-19 diseluruh dunia yang mengakibatkan kegiatan belajar mengajar baik disekolah dan perguruan tinggi dilaksanakan secara online. Belajar secara online menuntut kemandirian siswa untuk belajar sendiri dengan catatan guru tetap memantau proses pembelajaran siswa melalui aplikasi yang digunakan. Sembiring dan Siregar (2020:53) menyatakan bahwa guru memiliki peranan yang sangat penting dalam perbaikan mutu pendidikan, sebab guru akan menciptakan siswa yang berkualitas melalui pembelajaran.

Berdasarkan studi pendahuluan yang dilakukan peneliti, materi eksponen merupakan salah satu materi dimana siswa banyak melakukan kesalahan dalam menyelesaikan soal. Adapun kesalahan yang dilakukan siswa dalam menyelesaikan soal eksponen pada studi pendahuluan tersebut yaitu, kesalahan prinsip dan kesalahan proses penyelesaian. Dari hasil analisis jawaban tes, siswa melakukan kesalahan prinsip karena siswa tidak memahami penerapan sifat-sifat operasi dalam memecahkan masalah bilangan eksponen. Sedangkan pada proses penyelesaian, siswa salah karena tidak tepat dalam mengubah bentuk matematika dengan benar. Hasil studi pendahuluan dapat dilihat pada gambar dibawah ini.

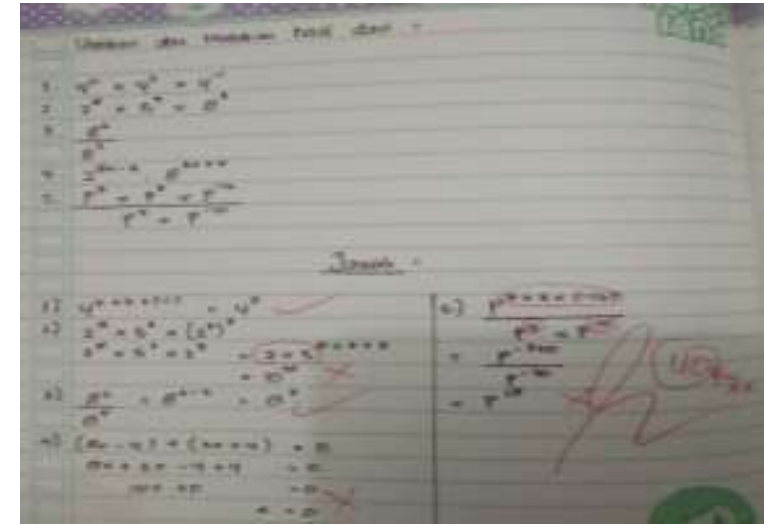

Gambar 1. Salah satu kesalahan siswa dalam menyelesaikan soal eksponen

Hal ini didukung dengan hasil wawancara bersama guru bidang studi Matematika SMA Swasta Tamansiswa Binjai Bapak Hari Wibowo, S.Pd yang menyatakan bahwa siswa merasa kesulitan untuk memahami materi yang disampaikan secara online. Sehingga kesulitan-kesulitan yang dialami siswa pada akhirnya mengakibatkan banyaknya siswa yang mengalami kesalahan dalam menyelesaikan soal matematika. Bukan hanya itu saja, jika siswa diberi soal yang sedikit bervariasi, mereka akan merasa bingung karena tidak tahu rumus mana yang harus mereka gunakan dan bagaimana langkah-langkah untuk menyelesaikan soal tersebut. Dengan kata lain, siswa tidak mampu berpikir kreatif untuk memecahkan suatu masalah matematika. Sejalan dengan pendapat Afni (2020:9) bahwa dalam proses pembelajaran, siswa kurang didorong untuk mengembangkan kemampuan berpikir. Proses pembelajaran diarahkan kepada kemampuan seseorang untuk menghafal informasi.

Selanjutnya, pada penelitian ini peneliti menggunakan aplikasi WhatsApp sebagai media pembelajaran online guna menganalisis kesalahan-kesalahan yang dilakukan siswa pada saat menyelesaikan soal, khususnya soal eksponen. Menurut Rusdianto (2015:19) analisis kesalahan dapat diartikan sebagai 
suatu teknik untuk mengidentifikasikan, mengklarifikasikan, dan menginterpretasikan secara sistematis kesalahan-kesalahan yang dibuat siswa yang sedang belajar menggunakan teori-teori dan prosedurprosedur. Berdasarkan jurnal penelitian Karnasih (2015:43) yang berjudul "Analisis Kesalahan Newman Pada Soal Cerita" menyimpulkan bahwa dalam beberapa studi yang dilakukan disekolah-sekolah, proporsi kesalahan terbesar sekitar $70 \%$ dari kesalahan yang dilakukan oleh siswa pada soal matematika yang khusus berada ditingkat pemahaman atau transformasi.

Menurut Loc dan Tong dalam (Widhiyassifah 2018:3) anak-anak melakukan banyak kesalahan dalam menyelesaikan soal seperti : subjektifitas, kecerobohan, salah penerapan aturan perhitungan, identifikasi jenis masalah yang salah dan salah dalam perhitungan. Hasil penelitian yang dilakukan oleh Junaedi, dkk (2015:40) kesalahan siswa dalam menyelesaikan soal dapat disebabkan oleh : (1) Siswa tidak mengetahui arti simbol atau istilah yang ada dalam masalah (Kesalahan Membaca), (2) Siswa tidak mengerti makna masalahnya (Kesalahan Pemahaman), (3) Siswa lupa formula yang akan digunakan atau strategi/prosedur apa yang harus dilakukan (Kesalahan Transformasi), (4) Siswa tidak bisa membuat pemecahan masalah algoritma secara berurutan dan benar (Kesalahan Proses Penyelesaian), (5) Siswa tidak bisa menjawab sesuai dengan pertanyaan (Kesalahan Menarik Kesimpulan).

Sedangkan menurut Prabowo (2014:25) jenis kesalahan yang dilakukan siswa dalam pelajaran matematika yaitu (1) Kesalahan Fakta atau simbo matematika (2) Kesalahan Konsep, (3) Kesalahan Operasi Perhitungan, (4) Kesalahan Prinsip. Berdasarkan uraian diatas tentang kesalahan-kesalahan yang dilakukan siswa, maka fokus utama kesalahan yang digunakan peneliti pada penelitian ini yaitu kesalahan konsep, kesalahan prinsip, dan kesalahan proses penyelesaian. Tujuan dari penelitian ini, yaitu : (1) Mendeskripsikan kesalahan yang paling banyak dilakukan siswa dalam menyelesaikan soal eksponen, (2) mendeskripsikan jenisjenis kesalahan yang dilakukan siswa dalam menyelesaikan soal eksponen.

\section{METODOLOGI PENELITIAN}

Penelitian ini dilaksanakan di SMA Swasta Tamansiswa Binjai pada semester ganjil. Jenis penelitian yang digunakan adalah deskriptif kuantitatif. Populasi pada penelitian ini yaitu seluruh siswa kelas X SMA Swasta Tamansiswa Binjai yang berjumlah 103 siswa. Melalui teknik Random Sampling, maka diperoleh sampel penelitian dari kelas $\mathrm{X}$ IPA 1 yang berjumlah 33 siswa. Teknik pengumpulan data yang digunakan meliputi soal tes diagnostik dan dokumentasi. Soal tes diagnostik dalam penelitian ini berbentuk uraian yang sebelumnya telah diuji validitasnya. Kemudian, teknik analisis data yang digunakan dalam penelitian ini adalah teknik analisis data deskriptif kuantitatif, yaitu menghitung besar tiap-tiap aspek kesalahan yang dilakukan siswa dalam bentuk persentase, yang selanjutnya dianalisis dengan cara mendeskripsikan data yang telah terkumpul sesuai dengan aspek kesalahan yang dilakukan siswa. Proses analisis terhadap lembar jawab siswa sebagai berikut : (1) Memeriksa jawaban pada lembar jawab siswa, (2) Menghitung persentase siswa yang salah dalam mengerjakan soal pada tiap aspek kesalahan, (3) Mengurutkan persentase aspek 
kesalahan siswa, (4) Mendeskripsikan data yang sudah dikelompokkan berdsarkan aspek kesalahan.

\section{HASIL DAN PEMBAHASAN}

Pelaksanaan penelitian ini dilakukan secara online dengan melalui aplikasi WhatsApp dengan alokasi waktu 60 menit. Penelitian dimulai dengan memberikan tes diagnostik kepada siswa terkait materi eksponen. Dalam pelaksanaannya, tes diberi sebanyak 2 kali pertemuan dengan bentuk soal yang hampir sama. Pada pertemuan I, hari Senin tanggal 28 September 2020, soal diberikan kepada siswa kelas X IPA 1 melalui grup WhatsApp. Setelah menganalisis lembar jawab siswa dan menghitung persentase yang salah dalam mengerjakan soal pada tiap aspek kesalahan maka besar persentase kesalahan yang dilakukan siswa dapat dilihat pada tabel dibawah ini.

Tabel 1. Persentase kesalahan siswa pada pertemuan I

\begin{tabular}{cc}
\hline Aspek & $\begin{array}{c}\text { Besar Persentase } \\
(\%)\end{array}$ \\
\hline Kesalahan Konsep & $19,71 \%$ \\
Kesalahan Prinsip & $37,87 \%$ \\
$\begin{array}{c}\text { Kesalahan Proses } \\
\text { Penyelesaian }\end{array}$ & $77,27 \%$ \\
\hline
\end{tabular}

Selanjutnya pada pertemuan II dihari Selasa tanggal 29 September 2020, soal diberikan kepada siswa kelas X IPA 1 melalui grup WhatsApp. Berdasarkan hasil analisis lembar jawab siswa dan menghitung persentase siswa yang salah dalam mengerjakan soal pada tiap aspek kesalahan, maka besar persentase kesalahan yang dilakukan siswa dapat dilihat pada tabel dibawah ini.

Tabel 2. Persentase kesalahan siswa pada
Jurnal Serunai Ilmu Pendidikan

Vol.6, No.2, Desember 2020

e-ISSN 2621 - 2676, p-ISSN 2528 - 0775 pertemuan II

\begin{tabular}{cc}
\hline Aspek & Besar Persentase (\%) \\
\hline Kesalahan Konsep & $10,61 \%$ \\
Kesalahan Prinsip & $46,97 \%$ \\
$\begin{array}{c}\text { Kesalahan Proses } \\
\text { Penyelesaian }\end{array}$ & $65,15 \%$ \\
\hline
\end{tabular}

Berdasarkan tabel 1 dan 2 bahwa kesalahan yang paling banyak dilakukan siswa dalam menyelesaikan soal eksponen adalah kesalahan dalam proses penyelesaian dengan persentase kesalahan sebesar $77.27 \%$ dan $65,15 \%$. Siswa salah pada proses penyelesaian karena siswa tidak memahami bagaimana prosedur atau langkah-langkah yang digunakan untuk menyelesaikan soal tersebut. Dari hasil analisis data diperoleh jenis-jenis kesalahan yang dilakukan siswa dalam menyelesaikan soal pada materi eksponen, yaitu sebagai berikut :

Kesalahan Konsep

Pada pertemuan I, siswa yang mengikuti tes atau siswa yang mengirimkan jawaban berjumlah 28 siswa dari 33 siswa. Artinya, ada 5 siswa yang tidak mengikuti tes atau tidak mengirimkan jawabannya. Kemudian, dari 28 orang siswa terdapat 12 siswa yang melakukan kesalahan dengan persentase kesalahan sebesar $19,71 \%$.

Pada pertemuan II, siswa yang mengikuti tes atau siswa yang mengirimkan jawaban berjumlah 25 siswa dari 33 siswa. Artinya, ada 8 siswa yang tidak mengikuti tes atau tidak mengirimkan jawabannya. Kemudian, dari 25 orang siswa terdapat 6 siswa yang melakukan kesalahan konsep dengan persentase kesalahan sebesar 10,61\%. Berikut salah satu contoh kesalahan konsep yang dilakukan siswa dapat dilihat pada gambar dibawah ini. 


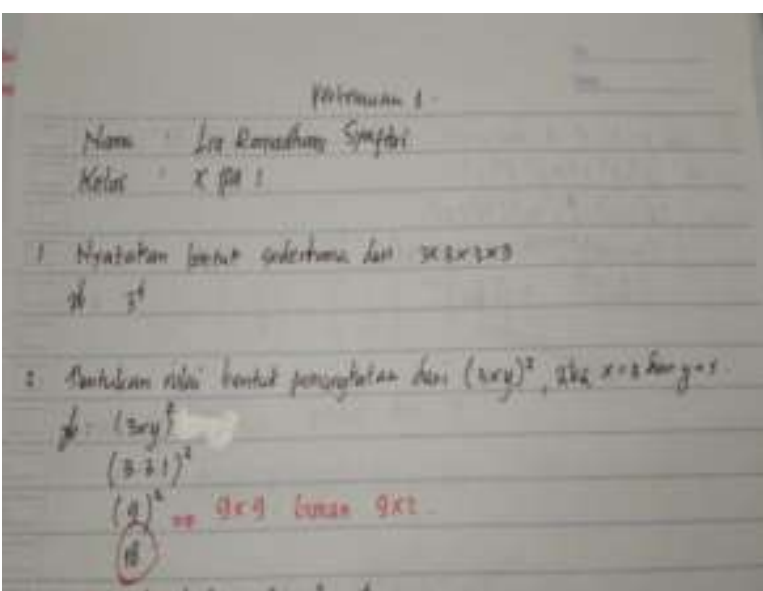

Gambar 2. Salah satu jawaban salah yang dilakukan siswa

Pada gambar diatas, siswa salah dalam memangkatkan angka 9 , yaitu $(9)^{2}=18$. Berdasarkan konsep eksponen yaitu $a^{n}=a \times a \times a \times \ldots \times a$, dimana $a$ dikali sebanyak $n$. Jadi, seharusnya $9^{2}=9 \times 9=81$, dimana angka 9 dikali sebanyak dua kali karena berpangkat 2. Hal ini menunjukkan bahwa siswa belum memahami konsep eksponen dengan baik.

Kesalahan Prinsip

Pada pertemuan I, siswa yang mengikuti tes atau siswa yang mengirimkan jawaban pada berjumlah 28 dari 33 siswa. Artinya, ada 5 siswa yang tidak mengikuti tes atau tidak mengirimkan jawabannya. Kemudian, dari 28 orang siswa terdapat 24 siswa yang melakukan kesalahan prinsip dengan persentase kesalahan sebesar $37,87 \%$.

Pada pertemuan II, siswa yang mengikuti tes atau siswa yang mengirimkan jawaban berjumlah 25 siswa dari 33 siswa. Artinya, ada 8 siswa yang tidak mengikuti tes atau tidak mengirimkan jawabannya. Kemudian, dari 25 orang siswa terdapat 23 siswa yang melakukan kesalahan prinsip dengan persentase kesalahan sebesar 46,97\%. Berikut salah satu contoh kesalahan prinsip yang dilakukan siswa dapat dilihat pada gambar dibawah ini.

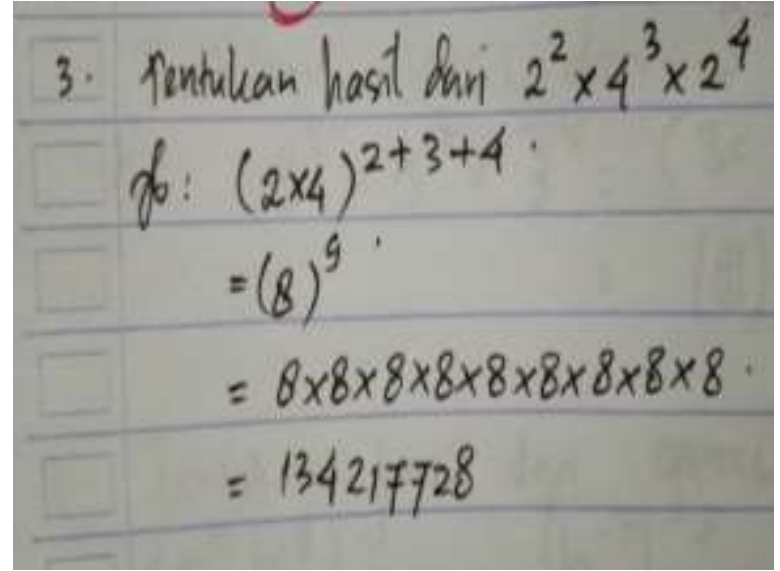

Gambar 3. Salah satu jawaban salah yang dilakukan siswa

Terlihat jelas pada gambar tersebut, siswa menyelesaikan soal dengan mengkalikan angka 2 dengan angka 4, lalu kemudian pangkatnya dijumlahkan. Berdasarkan sifat perkalian eksponen, pangkat dapat dijumlahkan apabila bilangan pokoknya sama, seperti berikut ini $a^{m} \times a^{n}=a^{m+n}$. Seharusnya, untuk menyelesaikan bentuk soal seperti nomor 3, langkah pertama yang harus dilakukan adalah menyamakan bilangan pokoknya terlebih dahulu, yaitu $2^{2} \times 4^{3} \times 2^{4}$ maka angka 4 dapat dinyatakan kedalam bentuk $2^{2}$. Sehingga, menjadi $2^{2} \times\left(2^{2}\right)^{3} \times 2^{4}$. Selanjutnya $2^{2} \times 2^{6} \times 2^{4}=2^{2+6+4}=2^{12}$. Kemungkinan yang terjadi siswa tidak memahami sifat-sifat eksponen sehingga terjadinya kesalahan pada prinsip.

Kesalahan Proses Penyelesaian

Pada pertemuan I, siswa yang mengikuti tes atau siswa yang mengirimkan jawaban berjumlah 28 siswa dari 33 siswa. Artinya, ada 5 siswa yang tidak mengikuti tes atau tidak mengirimkan jawabannya. Kemudian, dari 28 orang siswa semuanya melakukan 
kesalahan proses penyelesaian dengan persentase kesalahan sebesar 77,27\%.

Pada pertemuan II, siswa yang mengikuti tes atau siswa yang mengirimkan jawaban berjumlah 25 siswa dari 33 siswa. Artinya, ada 8 siswa yang tidak mengikuti tes atau tidak mengirimkan jawabannya. Kemudian, dari 25 orang siswa terdapat 22 siswa yang melakukan kesalahan proses penyelesaian dengan persentase kesalahan sebesar 65,15\%. Berikut salah satu contoh kesalahan prinsip yang dilakukan siswa dapat dilihat pada gambar dibawah ini.

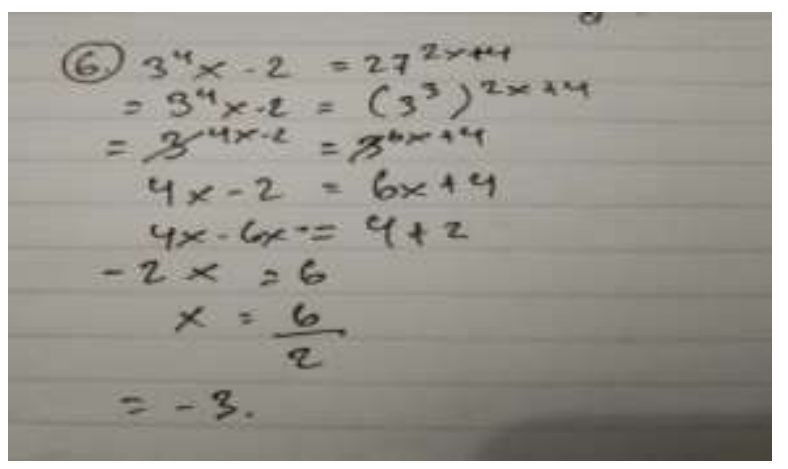

Gambar 4. Salah satu jawaban salah yang dilakukan siswa

Pada gambar 3.3, siswa salah dalam melakukan operasi hitung perkalian. Hal ini terlihat pada $\left(3^{3}\right)^{2 x+4}$ menjadi $3^{6 x+4}$, siswa mengalikan pangkat 3 dengan pangkat $2 x$, tetapi tidak mengalikan pangkat 3 dengan pangkat 4. Hal tersebut jelas termasuk pada kesalahan proses penyelesaian akibat kecerobohan siswa dalam operasi aritmatik, karena apabila langkah atau proses diawal sudah salah maka untuk proses pengerjaan selanjutnya akan salah. Harusnya $\left(3^{3}\right)^{2 x+4}=3^{6 x+12}$. Sehingga dapat disimpulkan bahwa ada beberapa siswa yang belum mampu menyelesaikan soal eksponen dengan benar sehingga terjadinya kesalahan pada proses penyelesaian.

Dari hasil tes diagnostik siswa pada pertemuan I dan pertemuan II, maka solusi untuk mengurangi kesalahan siswa dalam menyelesaikan soal eksponen diantaranya yaitu menyusun program perbaikan, model pembelajaran yang diberikan harus lebih kreatif, siswa harus lebih teliti dalam mengerjakan soal-soal, guru harus lebih dekat dengan siswa untuk mengetahui masalah yang dialami siswa yang dapat menyebabkan terjadinya kesalahan dalam menyelesaikan soal, dan lain sebagainya.

Hal yang sama juga dikemukakan dalam penelitian Retnaviar Widhiyassifah (2018) yang berjudul "Analisis Kesalahan Dalam Menyelesaikan Soal Eksponen Pada Siswa Kelas X Di SMA Negeri 1 Kartasura" bahwa terdapat 3 jenis kesalahan yang dilakukan siswa yaitu kesalahan transformasi dengan persentase kesalahan sebesar $23,81 \%$, kemudian kesalahan proses penyelesaian dengan persentase kesalahan sebesar $34,01 \%$, dan kesalahan menarik kesimpulan dengan persentase kesalahan sebesar 42,18\%. Jadi, dapat disimpulkan bahwa aspek kesalahan yang paling banyak dilakukan siswa adalah aspek kesalahan menarik kesimpulan dengan persentase sebesar $42,18 \%$.

\section{KESIMPULAN}

Berdasarkan hasil penelitian, jenis-jenis kesalahan pada penelitian ini meliputi : (a) Kesalahan konsep dengan persentase pada pertemuan I sebesar $19,71 \%$ dan pertemuan II sebesar 10,61\%, (b) Kesalahan prinsip dengan persentase pada pertemuan I sebesar 37,87\% dan pertemuan II sebesar 46,97\%, (c) Kesalahan proses penyelesaian dengan persentase pada pertemuan I sebesar 77,27\% dan pertemuan II sebesar $65,15 \%$. Dari hasil analisis dan perhitungan persentase pada setiap jenis-jenis kesalahan, maka kesalahan yang paling banyak dilakukan siswa adalah kesalahan dalam proses penyelesaian. 
Kemudian, alternatif solusi untuk mengurangi kesalahan siswa dalam menyelesaikan soal eksponen diantaranya yaitu menyusun program perbaikan, model pembelajaran yang diberikan harus lebih kreatif, siswa harus lebih teliti dalam mengerjakan soal-soal, guru harus lebih dekat dengan siswa untuk mengetahui masalah yang dialami siswa yang dapat menyebabkan terjadinya kesalahan dalam menyelesaikan soal, dan lain sebagainya.

\section{DAFTAR PUSTAKA}

Afni, Khairina. (2020). Penerapan Model Pembelajaran Problem Based Learning Terhadap Hasil Belajar Biologi Siswa Pada Materi Pokok Sistem Pencernaan Pada Manusia Di SMKS-PP Putra Jaya Stabat. Jurnal Serunai Ilmu Pendidikan. 6(1): 9-14

Junaedi, I., Suyitno, A., Sugiarto, E., \& Eng, C. K. (2015). Disclosure Causes of Students Error In Resolving Discrete Mathematics Problem Based on Nea as a Means of Enhanching Creativity. International Journal of Education. 7(4):31-42

Karnasih, Ida. (2015). Analisis Kesalahan

Newman Pada Soal Cerita Matematis.

JurnalParadikma FMIPA Unimed Medan. 8(1): 37-51

Prabowo, A.A. (2014). Analisis Kesalahan Siswa Kelas X SMA 1 Islam Gamping Yogyakarta Dalam Menyelesaikan Soal Matematika Yang Berkaitan Dengan Bilangan Berpangkat Dan Bentuk Akar. Skripsi pada Fakultas Matematika dan Ilmu Pengetahuan Alam Universitas Negeri Yogyakarta: tidak diterbitkan.
e-ISSN 2621 - 2676, p-ISSN 2528 - 0775

Rusdianto, H.D. (2015). Analisis Kesalahan Siswa Kelas VII-G SMP Negeri 1 Tulangan Sidoarjo Dalam Menyelesaikan Masalah-Masalah Perbandingan Bentuk Soal Cerita. Skripsi pada Fakultas Tarbiyah, Institut Agama Islam Negeri Sunan Ampel Surabaya: tidak diterbitkan.

Sembiring, Riska Febriani dan Siregar, R. Maisaroh. (2020). Pengaruh Model Pembelajaran Think Pair Share (TPS) Terhadap Kemampuan Komunikasi Matematika Siswa Kelas X SMA Melati Binjai Tahun Pelajaran 2019/2020. Jurnal Serunai Matematika. 12(1): 52-59

Widhiyassifah, Retnaviar. (2018). Kesalahan Dalam Menyelesaikan Soal Eksponen Pada Siswa SMA. Publikasi Ilmiah pada Fakultas Keguruan dan Ilmu Pendidikan Universitas Muhammadiyah Surakarta: tidak diterbitkan. 